\title{
PELAKSANAAN MANAJEMEN PROGRAM GERAKAN MASYARAKAT MAGRIB MENGAJI DI PROVINSI SUMATERA BARAT (STUDY KOMPARATIF DI TIGA DAERAH)
}

\author{
Delfi Indra \\ Guru PAI SDN 09 Tanah Garam Kota Solok, \\ Koresponden : Perumahan Solok Permata Indah Blok D No.151 Gelanggang Betung Kota Solok \\ e-mail: indradelfi@gmail.com
}

\begin{abstract}
Program Manajement Implementation Magrib Koran In West Sumatra province. The purpose of this study was to determine the Implementation of Program Management Society Movement Maghrib Koran in the province of West Sumatra in Jorong Gantiang Nagari Padang Magek Tanah Datar District of propagation, Jorong Nagari Koto Baru Bukit Kili lemur District of Solok District and Village Laing Solok District of Cape of Good Hope. The research method I use is Qualitative data collection techniques (1) Observation, (2) Interview and (3) Study of Documentation. The data were analyzed by means of data reduction, data presentation and inclusion.

The results of this study were (1) Management of the program sunset Koran society movements in the three regions are very different in practice, it looks at Jorong Gantiang have excellent management, Jorong Bukit Kili implement the program management has not been as good and Laing Village management has yet to implement this program as it should, it looks a lack of support from the town and village governments (2) Activities conducted in community programs dusk chanting movement is also different in each of these areas, in Jorong Gantiang there are 10 activities performed by generating a characteristic regions such as customary speech Pasambahan, in Bukit Kili Jorong no 7 Sub Laing activity while only 5 activity. and that (3) The effect that appears to the public is also different in the three regions, as in Jorong Gantiang communities already praying in congregation in Mushalla Nurul Hidayah and their home each with their own awareness, while the Mount Kili community Jorong sunset prayers in congregation in the Masjid Al-Ikhwan and implement program activities in the dusk Koran, and the Village Laing has not appeared influence on society The conclusion of this study is necessary active role of all components of society that exist in every region in the implementation of this Koran dusk society movement, especially in the area being built in this program. This study also gives the meaning, especially in the province of West Sumatra, so this program really accomplished in accordance with the expectations of society and government.
\end{abstract}

Kata Kunci: Manajemen, gerakan masyarakat, maghrib mengaji

\section{PENDAHULUAN}

Al-Qur'an adalah kalamullah firman Allah Swt yang diturunkan kepada Nabi
Muhammad SAW. Ia adalah kitab suci umat Islam yang merupakan sumber petunjuk dalam beragama dan pembimbing dalam menjalani kehidupan di dunia dan akhirat. 
betapa sempurnanya Al-Qur'an dengan hukum-hukum dan ajaran-ajaran Allah SWT yang tetap aktual dan akurat. Ia berbicara tentang berbagai sisi dan sudut kehidupan, baik tentang akidah, ibadah, etika pergaulan sesama manusia dan alam sekitarnya, politik, ekonomi dan lain sebagainya. Oleh karena itu, merupakan suatu kewajiban bagi seorang muslim untuk selalu berinteraksi aktif dengan Al-Qur`an, menjadikannya sebagai sumber inspirasi, berpikir dan bertindak. Membaca Al-Qur`an merupakan langkah pertama dalam berinteraksi dengannya, kemudian diteruskan dengan tadabbur yaitu dengan merenungkan dan memahami maknanya sesuai petunjuk salafus shalih, lalu mengamalkannya dalam kehidupan sehari-hari, kemudian dilanjutkan dengan mengajarkannya.

Dengan mengaji banyak sekali manfaat luar biasa yang tidak kita sadari yaitu dari segi afektif. Mengaji secara tidak langsung mampu mempengaruhi sifat kita menjadi lebih peka terhadap sifat ketuhanan, mereka sadar akan keberadaan Allah SWT, segi kognitif dengan menghafal surat pendek atau membaca susunan ayat Al-Qur'an dengan susunan tertentu atau menerjemah akan memperkuat struktur otak kita, kemampuan mengingat dan menggunakan daya nalar. Dulu kenyataan yang kita alami anak-anak tingkat sekolah dasar lebih mudah diajak mengaji ke masjid atau mushalla, bahkan tanpa ada suruhan dari orang tua karena biasanya mereka lebih cenderung akan mengikuti kemana orang tuanya pergi, jika orang tuanya pergi ke masjid atau mushalla maka tanpa diajakpun mereka akan ikut ke masjid atau mushalla, bahkan parahnya jika orang tuanya menonton televisi pada waktu magrib, mereka kemungkinan besar akan menonton televisi pada saat itu juga.

Dalam beberapa tahun terakhir, Menteri Agama Republik Indonesia, Bapak Drs.H.Suryadharma Ali, begitu bersemangat meminta kepada seluruh jajarannya baik level provinsi, kabupaten/kota, kecamatan maupun tingkat desa/jorong agar melaksanakan Program Gerakan Masyarakat Magrib Mengaji di seluruh Indonesia. Program ini disampaikan melalui Direktur Jenderal Bimbingan Masyarakat Islam saat itu Bapak Prof.Dr.H.Nasaruddin Umar,MA agar umat dibentengi untuk memelihara keluhuran budaya bangsa. Secara resmi program ini dicanangkan oleh Menteri Agama Republik Indonesia pada Tanggal 30 Maret $2011 \mathrm{di}$ Jakarta. Program tersebut muncul bukan dari ruang kosong, tetapi merupakan sebuah gagasan cemerlang sekaligus bentuk nyata dari upaya Menteri Agama untuk menangkal kecenderungan masyarakat (umat Islam) yang semakin hari semakin jauh dari nilai-nilai agama. Oleh karena itu, Program Gerakan Nasional Masyarakat Magrib Mengaji yang dipelopori oleh Menteri Agama Republik Indonesia menemukan signifikasinya. Program ini merupakan sebuah terobosan di tengah kuatnya arus modernisasi yang menawarkan keindahan duniawi.

Harapan masyarakat dari pelaksanaan program ini, setidaknya bermanfaat untuk : 1).Melestarikan tradisi "mengaji", bertadarrus, serta mengkaji Al-Qur'an dan ilmu agama selepas Shalat Magrib dalam rangka meningkatkan kualitas keshalehan 
individual dan sosial yang ditandai dengan meningkatnya kualitas ketaatan beragama melalui pembiasaan belajar agama. 2).Membentuk sikap dan perilaku moral masyarakat berdasarkan nilai-nilai Islam yang diukur dari integritas, kejujuran, disiplin dan loyalitas dalam menjalankan ajaran agamanya untuk membendung dampak negatif dari modernisasi ilmu pengetahuan dan teknologi informasi. 3).Membangun rekayasa sosial (social engineering) yang didasarkan pada semangat kearifan local dan nilai-nilai spiritual sebagai pondasi bagi terciptanya karakter bangsa yang berkeadaban menuju masyarakat madani. 4).Melahirkan generasi yang kuat, beriman dan bertakwa yang memiliki prinsip dan keteguhan dalam menghadapi tantangan kehidupan modern baik dalam tataran individu, keluarga, masyarakat, maupun bangsa. 5).Menjadikan Program Gerakan Magrib Mengaji sebagai media untuk membangun ikatan yang kuat dalam rangka membentuk keluarga.

Berdasarkan hasil survey awal yang penulis lakukan di lapangan yaitu Pertama di Jorong Gantiang Nagari Padang Magek Kecamatan Rambatan Kabupaten Tanah Datar, Program Gerakan Masyarakat Magrib Mengaji telah dilaksanakan dengan sangat baik, masyarakat setelah selesai Shalat Magrib mengaji atau membaca Al-Qur'an. Program ini tidak hanya mengaji setelah selesai Shalat Magrib, namun ada kegiatan lainnya seperti Wirid yasin remaja, Tafsir Al-Qur'an, Pembinaan penyelenggaraan jenazah, Pidato adat pasambahan, Wirid umum, Yasinan umum/ wirid yasin, Zikir bersama, Didikan subuh MDA setiap hari minggu pagi dan Kegiatan qasidah rebana, kegiatan ini dipusatkan pelaksanaannya di Mushalla Nurul Hidayah dan di rumah-rumah masyarakat.

Kedua, di Jorong Bukit Kili Nagari Koto Baru Kecamatan Kubung Kabupaten Solok, Program Gerakan Masyarakat Magrib Mengaji ini juga telah dilaksanakan secara rutin, program ini tidak hanya mengaji setelah selesai Shalat Magrib namun ada kegiatan lainnya seperti Wirid umum, Wirid subuh, Kegiatan remaja masjid, Seni Al-Qur'an, Wirid yasinan umum dan Didikan subuh MDA, kegiatan ini dipusatkan di Masjid Al-Ikhwan Air Panas Jorong Bukit Kili Air Panas Bukit Kili dan juga dirumah-rumah masyarakat.

Dan yang Ketiga, di Kelurahan Laing Kecamatan Tanjung Harapan Kota Solok, Program Gerakan Masyarakat Magrib Mengaji ini tidak hanya mengaji setelah selesai Shalat Magrib, namun ada kegiatan lain seperti Wirid bulanan, Seni Al-Qur'an, Didikan subuh dan Seni Qasidah Rebana. Kegiatan ini dipusatkan pelaksanaannya di Masjid Baitul Mukmin dan di rumah-rumah masyarakat, namun kegiatan ini tidak terlaksana secara rutin . Dari hasil survey awal ini penulis berkesimpulan bahwa Pelaksanaan Manajemen Program Gerakan Masyarakat Magrib Mengaji di tiga daerah ini sangat berbeda dalam pelaksanaannya.

Atas dasar itulah, penulis tertarik untuk melihat Bagaimana Pelaksanaan Manajemen Program Gerakan Masyarakat Magrib Mengaji ini di tiga daerah tersebut, maka dari itu penulis mengambil judul penelitian ini dengan : "Pelaksanaan Manajemen Program Gerakan Masyarakat Magrib Mengaji di 
Provinsi Sumatera Barat ( Studi Komparatif Tiga Daerah )".

\section{PEMBAHASAN}

\section{Manajemen}

Manajemen adalah ilmu dan seni mengatur proses pemanfaatan sumber daya manusia dan sumber-sumber lainnya secara efektif dan efisien untuk mencapai suatu tujuan tertentu. Istilah manajemen memiliki berbagai pengertian. Secara universal manajemen adalah penggunaan sumber daya organisasi untuk mencapai sasaran dan kinerja untuk tinggi dalam berbagai tipe organisasi profit maupun non profit.

Definisi manajemen sebagaimana yang dikemukakan oleh Daft adalah: "Management is the attainment of organizational goals in an effective and efficient manner through planning organizing leading and controlling organizational resources”. Maksudnya adalah bahwa manajemen merupakan pencapaian tujuan organisasi dengan cara yang efektif dan efisien lewat perencanaan pengorganisasian pengarahan dan pengawasan sumber daya organisasi.

Sementara Plunket dkk., mendefinisikan manajemen sebagai:

"One or more managers individually and collectively setting and achieving goals by exercising related functions(planning organizing staffing leading and controlling) and coordinating various resources(information materials money and people)". artinya bahwa manajemen merupakan satu atau lebih manajer yang secara individu maupun bersama-sama menyusun dan mencapai tujuan organisasi dengan melakukan fungsi-fungsi terkait ( perencanaan, pengorganisasian, penyusunan staf pengarahan dan pengawasan) dan mengkoordinasikan berbagai sumber daya yang ada.

Masing-masing orang dapat memandang manajemen sesuai dengan cara pandang mereka. walaupun berbeda dalam cara pandang, namun konsep manajemen tetap mengacu pada perencanaan, pengorganisasian, pengarahan, dan pengendalian.

1. Manajemen sebagai proses kegiatan

Suatu rangkaian kegiatan yang dimulai dari kegiatan merencanakan, melaksanakan serta mengkoordinasikan apa yang direncanakan sampai dengan kegiatan mengawasi atau mengendalikannya. Dalam penelitian ini, penulis memandang bahwa manajemen program gerakan masyarakat Magrib mengaji ini merupakan serangkaian proses kegiatan.

2. Manajemen sebagai suatu ilmu dan seni

Upaya pencapaian tujuan dengan pendekatan (approach) menjelaskan fenomena dan gejala manajemen serta mentransformasikan dan mengidentifikasi proses manajemen berdasarkan kaidah ilmiah

3. Manajemen sebagai profesi

Mereka yang bekerja dalam organisasi dengan menggunakan keahliannya dikelompokkan dalam kelompok manajemen profesional. Manajemen sebagai kumpulan orang untuk mencapai tujuan setiap kegiatan yang dilakukan oleh dua orang atau lebih secara kooperatif dalam organisasi disebut sebagai aktivitas manajemen 
Fungsi-fungsi manajemen telah di kemukan oleh para sarjana yang dikutip oleh M. Manulang dalam karyanya yang berjudul Dasar-dasar manajanemen. Diantaranya:

a. Laous A. Allan : Leading, Organising, Planning, Controling.

b. Prajudi Atmosudarjo: Planning, Organising, Motivating, Actuating, Controling.

c. Winardi SE.: Planning, Organising, Coordinating, Actuating, leading, Comonikating, Controlling.

Pada hakekatnya bila dikombinasikan dari ketiga sarjana tersebut diatas, maka fungsifungsi manajemen adalah sebagai berikut :

1) Planning

2) Organizing

3) Actuating

4) Coordinating

5) Motivating

6) Leading

7) Comunicating

8) Controling

Fungsi-fungsi manajemen adalah serangkaian kegiatan yang dijalankan dalam manajemen berdasarkan fungsinya masing-masing dan mengikuti satu tahapan-tahapan tertentu dalam pelaksanaannya. Fungsi-fungsi manajemen, sebagaimana diterangkan oleh Nickels, McHug and $\mathrm{McHugh}$, terdiri dari lima fungsi, yaitu :

\section{a) Perencanaan}

Perencanaan di dalam menajemen sangat diperlukan, baik didalam menyelesaikan tugas maupun sebagai alat yang dapat membantu untuk menyelesaikan tugas-tugas tertentu.
Dan dengan adanya suatu perencanaan yang matang serta disesuaikan dengan situasi dan kondisi yang ada, dapat dijadikan pedoman bagi pelaksanaan di dalam melaksanakan tugas-tugasnya. Sebab apabila di dalam melakukan suatu pekerjaan tanpa diawali perencanaan yang matang maka pekerjaan itu tidak dapat diselesaikan dengan optimal dan efesien.

Pandangan diatas diperkuat oleh pendapat Q.U. Efendy beliau menyatakan bahwa planning atau perencanaan adalah aktivitas menetapkan tujuan dan tindakan-tindakan untuk mencapai tujuan. Dari pendapat tersebut dapat ditarik kesimpulan bahwa perencanaan adalah merupakan rangkaian kegiatan secara teratur yang dilakukan oleh seseorang atau beberapa orang untuk mencapai tujuan tertentu.

Suatu perencanaan dalam sebuah menajeman baik berupa organisasi kecil atau besar, harus diatur dengan baik, serta harus memenuhi unsur-unsur yang harus ada didalam suatu perencanaan diantaranya :

(1) What: Apa yang akan dikerjakan. Ini menyangkut tujuan

(2) Where: Dimana akan dikerjakan, ini menyangkut lokasi karenanya harus dipertimbangkan dengan tepat.

(3) How: Bagaimana cara mengerjakan, ini berhubungan dengan tata cara melaksanakan kegiatan.

(4) Who: Siapa yang mengerjakan, hal ini berhubungan dengan orang yang melaksakan. 
(5) When: Kapan dikerjakan, ini menyangkut masalah waktu pelaksanaan.

(6) Why: Mengapa dikerjakan, ini menyangkut kegunaan manfaat dan kegiatan.

\section{b) Pengorganisasian}

Organisasi merupakan suatu wadah bagi manusia untuk melakukan kegiatan dalam mencapai tujuan bersama. Sedangkan dalam sebuah kelompok organisasi diperlukan atau harus adanya pemimpim dan yang dipimpin dalam melakukan kegiatannya. S.P. Siagian mengatakan: "Pengorganisasian adalah keseluruhan proses pengelompokan orangorang, alat-alat, tugas-tugas, tanggung jawab dan wewenang sedemikian rupa sehingga tercipta suatu organisasi yang dapat digerakkan sebagai suatu kesatuan dalam rangka mencapai tujuan yang telah ditentukan”.

Sedangkan menurut O.U Efendy pengorganisasian adalah kegiatan membagi-bagikan tugas kepada komponen-komponen aktivitas di antara para anggota kelompok. Dari beberapa pendapat tersebut dapat penulis ambil kesimpulan, bahwa pengorganisasian adalah penyusunan dan pembagian tugas kepada masing-masing anggota didalam suatu kelompok untuk mencapai tujuan yang telah ditentukan sebelumnya.

Agar suatu organisasi dapat berjalan dengan baik maka ada sesuatu yang perlu diperhatikan dan harus dijadikan sebagai pedoman sebagai prinsip organisasi, diantaranya adalah :
1. Harus menentukan tujuan yang jelas.

2. Harus ada sesuatau komando yang mengarah pada satu kesatuan.

3. Harus ada pembagian kerja yang baik dengan struktur organisasi yang jelas.

4. Harus ada pelimpahan wewenagn dan tanggung jawab.

5. Harus tersedianya alat-alat yang digunakan dan mencukupi menurut kebutuhan.

c) Pengimplementasian

Pengimplementasian atau Directing, yaitu proses implementasi program agar bisa dijalankan oleh seluruh pihak dalam organisasi serta proses memotivasi agar semua pihak tersebut dapat menjalankan tanggung jawabnya dengan penuh kesadaran dan produktivitas yang tinggi.

\section{d) Pengendalian}

Pengendalian dan pengawasan atau controlling, yaitu proses yang dilakukan untuk memastikan seluruh rangkaian kegiatan yang telah direncanakan, diorganisasikan, dan diimplementasikan bisa berjalan sesuai dengan target yang diharapkan sekalipun berbagai perubahan terjadi dalam lingkungan dunia bisnis yang dihadapi.

e) Evaluasi

Salah satu tahap pelaksanaan manajemen itu secara langsung maupun tidak langsung sudah sering kita lakukan. Kita melakukan evaluasi cakupan akses sanitasi dasar kita, jamban improved kita,laik sehat rumah makan dan restoran kita dan 
lain sebagainya. Berdasarkan waktu, kita melakukan evaluasi itu di akhir tahun untuk kepentingan penyusunan rencana kerja. Atau evaluasi pada pertengahan kegiatan untuk kepentingan repoting dan recording kegiatan kita.

Menurut Azwar, evaluasi adalah suatu proses yang teratur dan sistematis dalam membandingkan hasil yang dicapai dengan tolak ukur atau kriteria yang telah ditetapkan kemudian dibuat suatu kesimpulan dan penyusunan saran pada setiap tahap dari pelaksanaan program.

Tujuan evaluasi adalah meningkatkan mutu program, memberikan justifikasi atau penggunaan sumber-sumber yang ada dalam kegiatan, memberikan kepuasan dalam pekerjaan dan menelaah setiap hasil yang telah direncanakan.Suprihanto mengatakan bahwa tujuan evaluasi itu adalah sebagaman berikut ini :

(1) Sebagai alat untuk memperbaiki dan perencanaan program yang akan datang

(2) Untuk memperbaiki alokasi sumber dana, daya dan manajemen saat ini serta dimasa yang akan datang,

(3) Memperbaiki pelaksanaan dan dan faktor yang mempengaruhi pelaksanaan program perencanaan suatu program melalui kegiatan mengecek kembali.

Kegiatan-kegiatan dalam fungsi kegiatan manajamen dalam pelaksanaan sebuah program adalah :

a. Fungsi perencanaan (Planning)

1) Menetapkan tujuan dan target bisnis
2) Merumuskan strategi untuk mencapai tujuan dan target bisnis tersebut

3) Menentukan sumber-sumber daya yang diperlukan

4) Menetapkan standar/indikator keberhasilan dalam pencapaian tujuan dan target bisnis

b. Fungsi pengorganisasian (Organizing)

1) Mengalokasikan sumber daya, merumuskan dan menetapkan tugas, dan prosedur yang diperlukan

2) Menetapkan struktur ornganisasi yang menunjukkan adanya garis kewenangan dan tanggung jawab

3) Kegiatan perekrutan, penyeleksian, pelatihan, dan pengembangan sumber daya mansuia/tenaga kerja

4) Kegiatan penempatan sumber daya manusia pada posisi yang paling tepat

c. Fungsi pengimplementasian (Directing)

1) Mengimplementasikan proses kepemimpinan, bimbingan, dan pemberian motivasi kepada tenaga kerja agar dapat bekerja secara efektif dan efisien dalam pencapaian tujuan

2) Memberikan tugas dan penjelasan rutin mengenai pekerjaan menjelaskan kebijakan yang ditetapkan

d. Fungsi pengawasan (Controlling)

1) Mengevaluasi keberhasilan dalam pencapaian tujuan dan target bisnis sesuai dengan indikator yang telah ditetapkan

2) Mengambil langkah klarifikasi dan koreksi atas penyimpangan yang mungkin ditemukan 
3) Melakukan berbagai alternatif solusi atas bnerbagai masalah yang terkait dengan pencapaian tujuan dan target bisnis.

e. Fungsi evaluasi

1) Menyediakan pertanggungjawaban kegiatan kepada masyarakat, stakeholder, dan lembaga donor;

2) Membantu menentukan tujuan yang telah ditentukan pada perencanaan;

3) Meningkatkan program implementasi;

4) Memberikan kontribusi untuk pemahaman ilmiah tentang hasil suatu program;

5) Meningkatkan kesadaran, dukungan terhadap masyarakat

6) Menginformasikan kebijakan kepada masyarakat

\section{Pengertian Mengaji/Membaca Al-Quran}

Menurut Kementerian Agama RI Gerakan Masyarakat Mengaji adalah sebuah program untuk membudayakan membaca Al-Qur'an setelah selesai Shalat Magrib dikalangan masyarakat. Sementara menurut W.J.S Purwadarima yang dimaksud membaca adalah melihat tulisan dan mengerti atau dapat melisankan apa yang tertulis itu.

Mengaji selalu di identikkan dengan membaca Al Qur'an. Mungkin ini yang menjadi salah satu faktor penyebab kenapa orang-orang tidak mau karena tidak bisa dan malu. Padahal mengaji Al Qur'an adalah sesuatu yang sangat menyenangkan. Selain membaca, mengaji itu juga berarti memaknai dan mengartikan pengertiannya. Mengapa harus dimaknai? Karena Al Qur'an itu bahasa arab, yang tentunya kita sebagai orng indonesia sulit untuk tau artinya. Mengapa harus di artikan pengertiannya? Karena $\mathrm{Al}$ Qur'an berisi syair-syair Allah yang sangat indah, yang tentunya beberapa memiliki pengertian yang tersirat yang perlu di pahami.

Mengaji sendiri sebenarnya bukan sebuah alternatif. Tapi mengaji adalah sebuah kewajiban. Dimana tanpa mengaji maka semua amalan yang kita lakukan tentunya hanya bohong belaka. Tidak akan di terima oleh Allah SWT. Firman Allah SWT dalam Al-Qur'an Surat Fathir: 29-30 dan Al An-Kabut: 45

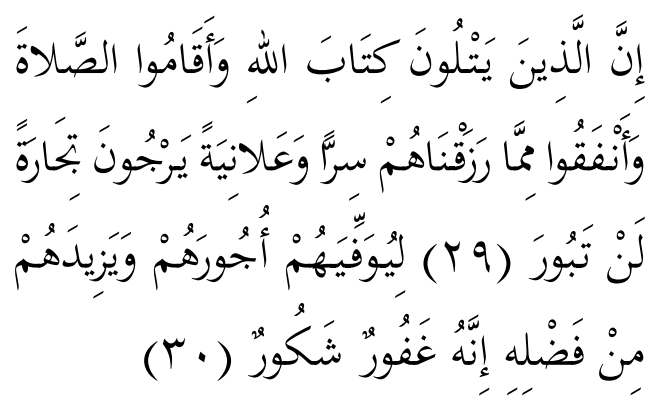

Sesungguhnya orang-orangyang selalu membaca kitab Allah dan mendirikan shalat dan menafkahkan sebahagian dari rezki yang Kami anugerahkan kepada mereka dengan diam-diam dan terang-terangan, mereka itu mengharapkan perniagaan yang tidak akan merugi agar Allah menyempurnakan kepada mereka pahala mereka dan menambah kepada mereka dari karuniaNya. Sesungguhnya Allah Maha Pengampun lagi Maha Mensyukuri. (QS. Fathir : 29-30)

Adapun di antara keutamaan membaca Al Qur'an dari sunnah Rasulullah SAW adalah:

1. Menjadi manusia yang terbaik:

"Dari Utsman bin 'Affan rad, dari Nabi saw, beliau bersabda:

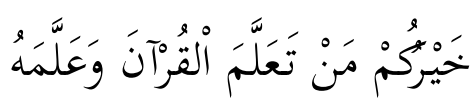

Sebaik-baik kamu adalah orang yang 
mempelajari Al Qur'an dan mengajarkannya." ( HR. Al-Bukhari)

2. Kenikmatan yang tiada bandingnya:

“ Dari Abdullah bin Umar RA, dari Nabi, beliau bersabda:

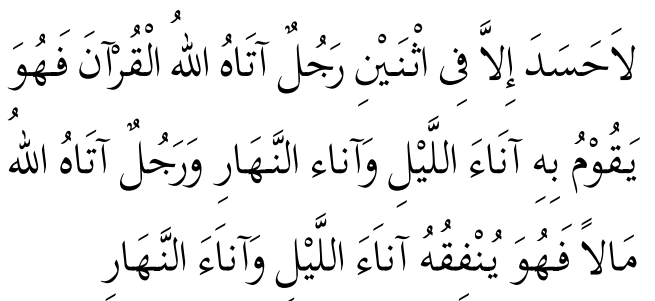

Tidak boleh ghibthah (menginginkan sesuatu yang dimiliki orang lain) kecuali dalam dua hal: (pertama) orang yang diberikan Allah SWT keahlian tentang al-Qur'an, maka dia melaksanakannya (membaca dan mengamalkannya) malam dan siang hari. Dan seorang yang diberi oleh Allah SWT kekayaan harta, maka ia infakkan sepanjang hari dan malam." (Muttafaqun alaih)

3. Al Qur'an memberi syafaat di hari kiamat: dari Abu Umamah al-Bahili RA, ia berkata, 'Saya mendengar Rasulullah SAW bersabda:

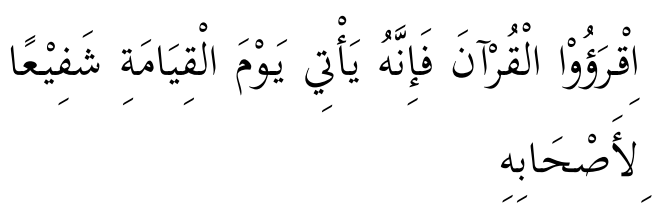

Bacalah al-Qur' an, sesungguhnya ia akan datang pada hari kiamat memberi syafaat bagi ablinya (yaitu orangyang membacanya, mempelajari dan mengamalkannya). (HR. Muslim)

4. Pahala berlipat ganda: dari Ibnu Mas'ud rad, ia berkata, 'Rasulullah SAW bersabda :

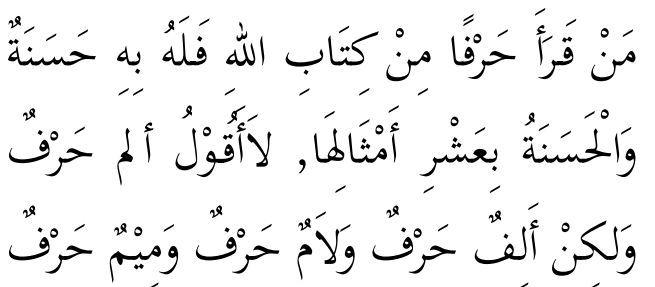

Barangsiapa yang membaca satu huruf dari Al Qur'an maka untuknya satu kebaikan, dan satu kebaikan dilipat gandakan dengan sepuluh kali lipat. Saya tidak mengatakan 'alif laam miim' satu huruf, akan tetapi alif adalah satu huruf, laam satu huruf dan miim satu huruf. (HR. At-Tirmidzi)

5. Dikumpulkan bersama para malaikat: dari Aisyah radhiyallahu 'anha, ia berkata, Nabi Muhammad SAW bersabda :

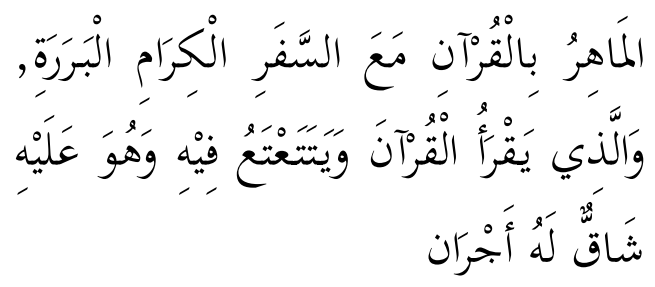

Orangyang membaca Al Qur'an dan ia mahir dalam membacanya maka ia dikumpulkan bersama para malaikat yang mulia lagi berbakti. Sedangkan orang yang membaca Al Qur'an dan ia masih terbata-bata dan merasa berat dalam membacanya, maka ia mendapat dua pahala. (Muttafaqun 'alaih)

Inilah sebagian dari anjuran dan keutamaan membaca Al-Qur'an, dan yang perlu diingat bahwa pahala membaca Al-Qur'an diperoleh bagi siapa pun yang membacanya, walau tidak memahami makna dan tafsirnya. Kendati demikian kalau bisa memahaminya pahalanya tentu lebih baik dan lebih banyak pahalanya. Sebagian ulama menyebutkan beberapa hikmah keistimewaan membaca AlQur'an yang pahalanya bisa diperoleh kendati tidak memahamainya

\section{Pengertian Gerakan Masyarakat Magrib Mengaji}

Gerakan Masyarakat Magrib Mengaji atau yang lebih dikenal dengan Gerakan Masyarakat Magrib Mengaji merupakan Program Nasional Kementerian Agama 
Republik Indonesia yang dicanangkan di tiap Provinsi dan Kabupaten / Kota se Indonesia. Gerakan Masyarakat Magrib Mengaji adalah sebuah program untuk membudayakan membaca Al Qur'an setelah Shalat Magrib di kalangan masyarakat. Membaca Al Qur'an atau mengaji sejak dulu telah menjadi budaya masyarakat Indonesia. Namun akhir-akhir ini mengaji sudah mulai ditinggalkan. Masjid atau Mushalla terkadang kosong, taktifitas pengajian sangat kurang. umat lebih asyik di depan televisi dari pada mengaji.

\section{Tujuan Gerakan Masyarakat Magrib Mengaji}

Tujuan dari Program Gerakan Masyarakat Magrib Mengaji ini adalah :

1. Melestarikan tradisi "mengaji", bertadarrus, serta mengkaji Al Qur'an dan ilmu agama selepas shalat Magrib dalam rangka meningkatkan kualitas kesalehan individual dan sosial yang ditandai dengan meningkatnya kualitas ketaatan beragama melalui pembiasaan belajar agama.

2. Menumbuhkan kesadaran di tengah-tengah masyarakat akan fungsi dan peranan $\mathrm{Al}$ Qur'an bagi kehidupan manusia sehingga Alqur'an tetap dibaca dan dipelajari sekalipun telah tamat (khatam) dari Taman Pendidikan Al Qur'an

3. Meningkatkan minat dan kemampuan masyarakat dalam membaca Alqur’an

4. Membentuk sikap dan perilaku moral masyarakat berdasarkan nilai-nilai Islam yang diukur dari integritas, kejujuran, disiplin dan loyalitas dalam menjalankan ajaran agamanya untuk membendung dampak negative dari modernisasi ilmu pengetahuan dan teknologi informasi.

5. Membangun rekayasa sosial (social engineering) yang didasarkan pada semangat kearifan local dan nilai-nilai spiritual sebagai pondasi bagi terciptanya karakter bangsa yang berkeadaban menuju masyarakat madani.

6. Melahirkan generasi yang kuat, beriman dan bertakwa yang memiliki prinsip dan keteguhan dalam menghadapi tantangan kehidupan modern baik dalam tataran individu, keluarga, masyarakat, maupun bangsa.

7. Menjadikan program Magrib Mengaji sebagai media untuk membangun ikatan yang kuat dalam rangka membentuk keluarga, meningkatkan kerjasama antara orang tua, masyarakat dengan unsur pendidikan dan pemerintah

8. Memakmurkan Masjid dengan gema ibadah dan membaca Al Qur'an guna meminimalisir pengaruh negatif dari media elektronik

Manfaat anak gemar mengaji sangat besar. Baik itu langsung maupun tidak langsung. Mamfaat lain dari Gerakan Masyarakat Magrib Mengaji ini adalah sebagai berikut :

a. Menghambat anak dalam mengikuti pergaulan yang berlebihan.

b. Memfilter pengaruh buruk dari luar

c. Menjadi anak yang berbakti pada orang tua

d. Anak lancar dalam membaca Al-Qur'an

\section{Landasan Yuridis}

Program Gerakan Masyarakat Magrib Mengaji mengacu kepada landasan yuridis sebagaimana berikut ini : 
1) Undang - undang Sistem Pendidikan Nasional (Sisdiknas) Nomor 20 Tahun 2003.

2) Peraturan Pemerintah Nomor 19 Tahun 2005 tentang Standar Nasional Pendidikan.

3) Peraturan Pemerintah Nomor 55 Tahun 2007 tentang Pendidikan Agama dan Keagamaan.

4) Surat Keputusan Bersama Menteri Dalam Negeri dan Menteri Agama Nomor 128 dan 44 A Tahun 1982 tentang Usaha Peningkatan Kemampuan Baca Tulis Huruf Al Quran Bagi Umat Islam dalam rangka Peningkatan Penghayatan dan Pengamalan Al Quran dalam kehidupan sehari-hari.

5) Instruksi Menteri Agama RI Nomor 3 Tahun 1990 tentang Pelaksanaan Upaya Peningkatan dan Kemampuan Baca Tulis Huruf Al Quran.

6) Peraturan Direktur Jenderal Bimbingan Masyarakat Islam No. Dj.II/606/2011 tentang pembinaan pengajian Tradisional Anak-anak.

7) Pencanangan Gerakan Masyarakat Magrib Mengaji oleh Menteri Agama RI, Suryadarma Ali, tanggal 30 Maret 2011 di Jakarta.

8) Peraturan Nagari Koto Baru Kecamatan Kubung Kabupaten Solok Nomor 2 Tahun 2013 tentang Program Gerakan Masyarakat Magrib Mengaji.

\section{Ketentuan Magrib Mengaji}

1. Jenis Kegiatan Program Gerakan Masyarakat Magrib Mengaji adalah:
a. Tilawatil Qur`an/Qira'ah
b. Tadarrus Al Qur`an
c. Tahfidzul Qur'an
d. Kajian Tafsir Al Qur`an

2. Lokasi Kegiatan

Lokasi kegiatan Program Gerakan Masyarakat Magrib Mengaji ini dapat dilakukan di Masjid, mushalla, surau, dan di masing-masing rumah masyarakat.

3. Waktu Pelaksanaan Kegiatan

4. Kegiatan Program Gerakan Masyarakat Magrib Mengaji ini dilakukan setelah selesai Shalat Magrib dan program ini sudah dimulai sejak Tahun 2011 sampai sekarang.

5. Tanggung Jawab kegiatan
a. Individu
b. Rumah Tangga / Keluarga
c. Instansi / Kantor
d. Badan Kemakmuran Masjid (BKM)
e. Tokoh Masyarakat
f. Sekolah / Madrasah
g. Pelaku Usaha / Pasar / Objek Wisata
1) Memasang spanduk di dalam/depan pasar atau objek wisata tentang Gerakan Masyarakat Magrib Mengaji.
2) Mensosialisasikan kepada pengunjung pasar/wisatawan bagaimana dan apa yang dimaksud dengan Gerakan Masyarakat Magrib Mengaji.
3) Membuat papan reklame tentang Gerakan Magrib Mengaji dan dipasang pada tempat-tempat strategis

6. Pembiayaan

Seluruh biaya untuk kegiatan ini berasal dari partisipasi masyarakat yang dapat melakukan kerjasama dengan semua pihak, bersinergi mensukseskan Program Gerakan Masyarakat Magrib mengaji yang sudah dicanangkan oleh pemerintah ini 


\section{PENUTUP}

Dari hasil penelitian ini dapat penulis simpulkan bahwa terdapat perbedaan manajemen dalam pelaksanaan Program Gerakan Masyarakat Magrib Mengaji (GEMMAR) di Sumatera Barat terutama di tiga daerah yang penulis teliti. Perbedaan manajemen tersebut terutama terlihat dari jenis kegiatan yang dilakukan oleh masingmasing daerah, sehingga hasil dan pengaruh yang ditimbulkan juga berbeda. Diantara perbedaan jenis kegiatan tersebut adalah:

\section{Jorong Gantiang Nagari Padang Magek Kecamatan Rambatan Kabupaten Tanah Datar}

Pada Jorong Gantiang ini kegiatan Program G-M3 yang dilakukan adalah Mengaji siap magrib, Wirid yasin remaja, Tafsir Al-Qur'an, Pembinaan penyelenggaraan jenazah, Pidato adat pasambahan, Wirid umum, Yasinan umum/wirid yasin, Zikir bersama, Didikan subuh MDA setiap hari minggu pagi, Kegiatan qasidah rebana

Diantara pengaruh yang timbul dari kegaiatan ini adalah :

a. Terbiasanya masyakat Jorong Gantiang mengaji setelah selesai Shalat Magrib, baik di mushalla maupun di rumah.

b. Terbiasanya masyarakat Jorong Gantiang melaksanakan Shalat Magrib dan Isya berjamaah baik di mushalla maupun di rumah

\section{Jorong Bukit Kili Nagari Koto Baru Kecamatan Kubung Kabupaten Solok}

Kegiatan Program G-M3 yang dilaksanakan di Jorong Bukit Kili adalah
Wirid umum, Wirid subuh, Kegiatan remaja masjid, Seni Al-Qur'an, Wirid yasinan umum, Didikan subuh MDA

Pengaruh yang ada di Jorong Bukit Kili dari program ini adalah:

a. Jorong Bukit Kili meraih juara 3 dalam Desa binaan Program Gerakan Masyarakat Magrib Mengaji Tingkat Propinsi Tahun 2013.

b. Wali Nagari Koto Baru Bapak Afrizal, K diundang ke Padang mengikuti HAB Depag Tahun 2013.

\section{Kelurahan Laing Kecamatan Tanjung} Harapan Kota Solok Provinsi Sumatera Barat

Kegiatan Program G-M3 yang dilakukan di Kelurahan Laing adalah Mengaji selesai magrib, Wirid bulanan, Seni Al-Qur'an, Didikan subuh, Seni Qasidah Rebana. Pengaruh program Gerakan Masyarakat Magrib Mengaji di Kelurahan Laing Kecamatan Tanjung Harapan Kota Solok Provinsi Sumatera Barat adalah:

a. Kelurahan Laing mewakili Kota Solok dalam lomba Desa Binaan dalam Program G-M3 Tahun 2012 Tingkat Sumatera Barat.

b. Masjid Baitul Mukmin mendapatkan dana bantuan meja dan kursi untuk dari Kementrian Agama Kota Solok tahun 2012.

\section{KEPUSTAKAAN ACUAN}

Abdul Halim Hanafi, Metodologi Penelitian Kependidikan, Batusangkar : STAIN Batusangkar Press,2013

A. M. Sardiman, Interaksi dan Motivasi Belajar Mengajar, Jakarta: Raja Grafindo Persada, 2004. 
Arikunto, Suharsini dan Safruddin, Cepi, Evaluasi Program Pendidikan Pedoman Teoritis Praktis Bagi Praktisi Pendidikan. Jakarta: Bumi Aksara, 2004.

Departemen Agama, Al Qur'an dan Terjemahnya, Jakarta: Depag, 1998.

E. Mulyasa, Manajemen Berbasis Sekolah, Bandung: Remaja Rosdakarya, 2004.

Hamlan, AB, Andi Malla, Kebijakan Pemerintah tentang Madrasah, Disertasi, UIN Syarif Hudayatullah, Jakarta: 2006.

Hasan Zaini, Radhiatul Hasnah,Pesan-pesan Al-Qur'an tentang Berbagai persoalan umat,Batusangkar : STAIN Batusangkar Press, 2011

Iin Tri Rahayu dan Tri Ardi Rahayu, Observasi dan Wawancara, Madang: Bayu Media, 2004.

Lexy, Maleong, Metode Penelitian Kualitatif. Bandung : Rosda, 2004.
Maftuhah, Pendidikan Politik di Madrasah, Tesis, UIN Syarif Hudayatullah, Jakarta: 2003.

Matthew B. Miles dan A. Michael Huberman, Analisis Data Kualitatif, Jakarta: UI-Press, 1992.

Muhammad bin Ibrahim bin Abdullah At Tuwaijry. Keutamaan Al- Qur'an, Sub. 3, Islamhouse.com, 2007.

Muslim Bin Al-Hajjaj, Shohih Muslim, Tanpa Tempat: Dar el - fikr, 1995.

Nur Faizah, Sejarah Al Qur'an, Jakarta: Artha Rivera, 2008.

Trisnawati Sule, Ernie, Pengantar Manajemen, Jakarta: Kencana.

Undang-Undang Sisdiknas (Sistem Pendidikan Nasional) Undang-undang Sistem Pendidikan Nasional (Sisdiknas) Nomor 20 Tahun 2003, Jakarta: Fokus Media, 2010. 